\title{
Carta das Editoras
}

A Associação de Linguística Aplicada do Brasil, com o apoio do Programa de Pós-Graduação em Estudos Linguísticos e do Departamento de Letras Anglo-Germânicas da Universidade Federal de Minas Gerais apresenta à comunidade acadêmica o segundo número da Revista Brasileira de Lingüística Aplicada.

Estamos felizes com a boa participação dos pesquisadores que ao enviar seus trabalhos contribuem para que seja mantida a periodicidade da revista.

Aproveitamos para comunicar aos nossos colaboradores que os organizadores decidiram produzir alguns números tematizados. Assim, o) terceiro número da revista terá como tema a tradução e publicará trabalhos selecionados dentre os apresentados no II Encontro Internacional de Tradutores. Essa edição está a cargo de Fábio Alves. O número quatro que deverá sair bem no início de 2003, já está sendo editado por Hcliana Mello e não terá restrição de tema, estando ainda aberto há outros trabalhos.

No segundo semestre de cada ano, haverá edições tematizadas. Vejam a relação de temas por ano:

Aprendizagem de línguas mediada por computador (2003)

Formação de professores (2004)

Cognição e aprendizagem de línguas (2005)

Avaliação de cursos e de aprendizagem de línguas (2006).

Ao antecipar os temas, temos a expectativa de produzir edições (fue consigam congregar um bom número de pesquisadores dos diversos colloques da Lingüística Aplicada no Brasil e no exterior.

\section{Nesta Edição}

Robert de Beaugrande, pesquisador visitante da UFMG/FAPEMIG - Linda Williams abrem este número, demonstrando as diferentes ‘uncepcö̌es (fue o termo "democracia" pode representar, através da análise de un corpus de lingua inglesa due réne textos orais e escritos coletados mai Alrica do Sus.

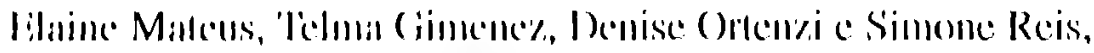

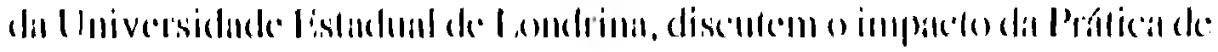


Ensino de Inglês na formação de licenciandos em Letras e demonstram as limitações dessa Prática no processo de aprender a ensinar.

Matilde Scaramucci relata pesquisa sobre o impacto da prova de Inglês do vestibular da UNICAMP nas atitudes, comportamentos e ações de professores em três contextos de ensino médio de Campinas: escola pública, particular e curso preparatório, concluindo que a influência que o exame em questão exerce no ensino não é determinista.

O estudo de Solange T. Castro, da Universidade de Taubaté, discute os resultados de oportunidades de aprendizagem, oferecidas a professores de inglês da rede pública estadual que indicam a emergência de novas concepções de linguagem presentes nas ações desses professores em processo reflexivo de formação.

Rosane Silveira, da Universidade Federal de Santa Catarina, investiga a interlíngua de brasileiros aprendendo inglês como língua estrangeira, focando, dentre outros fatores, a relação percepçãoprodução na aquisição de encontros consonantais iniciados $\mathrm{em} / \mathrm{s} /$, em início de palavra. Segundo a autora, seus resultados validam parcialmente outros estudos que propõem a influência da percepção sobre a produção.

Em sintonia com o trabalho de Mateus et al., Andréa Mattos, da Universidade Federal de Minas Gerais, também aponta as limitações na formação de professores nos Cursos de Letras, e retoma o tema, discutindo as mudanças percebidas no comportamento de uma professora de inglês em decorrência de sua participação em uma pesquisa que investigava a auto-observação dentro do modelo reflexivo para a formação de professor.

Luciana Rottava, da UNIJUÍ, defende a tese de que "as produções escritas do sujeito refletem as práticas sociais do que participa" através de resultados obtidos em uma investigação de produção textual de um falante bilíngüe (português e espanhol, sendo a primeira língua a nativa).

Nesta edição, temos ainda duas resenhas. Míriam Jorge relata que o último livro organizado por Vilson Leffa $O$ professor de línguas estrangeiras : construindo a profissão tenta responder à pergunta "Como se faz o professor de Língua Estrangeira"? Subdividida em outras quatro perguntas norteadoras: a) quais são as idéias que predominam na área de formação de professores?, b) como essas idéias são tratadas na prática?, c) o que mostram as pesquisas?, e d) o que se pode fazer para melhorar? e Maria Isabel Piccina apresenta aos leitores o livro didático (ompreensão)

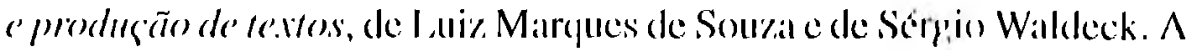


resenhista advoga que os autores antes de proporem os exercícios, conseguem apresentar de forma simples, procurando evitar jargões, a discussão teórica sobre produção de texto.

Deise Prina Dutra

Vera Lúcia Menezes de Oliveira e Paiva 


\section{Editors`Note}

The Brazilian Association of Applied Linguistics, with support from the Graduate Program in Linguistics and the Anglo-Germanic Languages Department of the Federal University of Minas Gerais offers the academic community the second edition of The Brazilian Journal of Applied Linguistics.

We are very pleased with the participation of those researchers who sent their work to us, so that this journal could continue to be regularly published.

We would like to take this opportunity to announce to our contributors that the organizers have decided to produce future journals on a thematic basis. Thus, the third in the series will have translation as its topic, publishing papers from among those presented at the Second International Translators' Convention. That edition is the responsibility of 'Fábio Alves. The fourth, scheduled to appear in the beginning of 2003, is already in the process of being edited by Heliana Mello and has no lliematic restrictions, being open to many types of topics.

The second semester of each year will see editions organized around a general theme. The future topics related to their respective years arc as follows:

Computer-assisted language learning (2003)

Teacher education (2004)

Language learning and cognition (2005)

Course evaluation and language learning (2006).

III proposing these topics, we anticipate producing editions that will bring wipellier a large number of researchers from various areas of Applied I Inguistics in Brazil and abroad.

\section{In 'I'his Edition}

Robert de Beaugrande, visiting scholar at UFMG/FAPEMIG, and I. Inllit Williams start off this edition, showing the differing notions that H11. 1crm "ckmocracy" call represent, through the analysis of a corpus of lmplish language that combines oral and written texts collected in South Alicit.

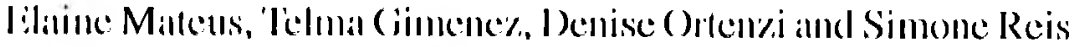

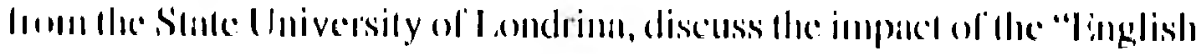


Teaching Practicum" in the education of Certified Language Teachers and demonstrate the limitations of the Practicum on the process of learning to teach.

Matilde Scaramucci shares her research on the impact of the English exam portion of UNICAMP's Entrance Exam on atittudes, behavior and actions of teachers in three contexts of secondary school in Campinas (São Paulo State): public, private and exam preparatory schools. She reaches the conclusion that the exam in question does not exert a deterministic influence on teaching.

The study written by Solange T. Castro, from the University of Taubate, discusses the results of learning opportunities offered to English teachers in the state school system. Such opportunities indicate the emergence of new ideas about language demonstrated by the actions of these teachers involved in reflective teaching.

Rosane Silveira, from the Federal University of Santa Catarina, investigates the interlanguage of Brazilians learning English as a foreign language, focusing on, among other factors, a perception-production relationship in the acquisition of consonant groupings beginning with $/ \mathrm{s} /$ at the beginning of a word. According to the author, the results partially validate other studies promoting the influence of perception on production.

In harmony with the research of Mateus et. al., Andréa Mattos from The Federal University of Minas Gerais, also draws attention to the limitations of the language teacher education, analyzing the behavioral changes observed in an English teacher, due to her participation in a study that investigated teacher education with a self-reflective approach.

Luciana Rottava, from UNIJUI, defends the hypothesis that "written work reflects the social practices of those who produce it". Her data comes from the results of an investigation of textual production of a bilingual speaker of Portuguese and Spanish, Portuguese being the subject's native language.

This edition also presents two critical reviews. Míriam Jorge tells us that the latest book put together by Vilson Leffa Foreign language teacher: constructing the profession attempts to respond to the question "How is a foreign language teacher made"? Four other questions form the book subdivisions: a) What are the most important concepts in the creation of teachers? b) How are these concepts treated in practice? c) What does the research show? and d) What can be done to improve the situation? 
Finally, Marria Isabel Piccina introduces readers to the textbook ( 'mmprehension and production of texts by Luiz Marques de Souza and d. S'rergio Waldeck. The reviewer states that the authors, before the presentation of the exercises, add a simpler, jargon-free, theoretical discussion of text production and comprehension.

\section{Deise Prina Dutra}

Vera Lúcia Menezes de Oliveira e Paiva 